MT-DP - 2015/53

Would depositors like to show others that they do not withdraw? Theory and Experiment

MARKUS KINATEDER - HUBERT JÁNOS KISS

- ÁGNES PINTÉR 
Discussion papers

MT-DP - 2015/53

Institute of Economics, Centre for Economic and Regional Studies, Hungarian Academy of Sciences

KTI/IE Discussion Papers are circulated to promote discussion and provoque comments. Any references to discussion papers should clearly state that the paper is preliminary.

Materials published in this series may subject to further publication.

Would depositors like to show others that they do not withdraw? Theory and Experiment

Authors:

Markus Kinateder

associate professor

Departamento de Economía, Edificio de Amigos, Universidad de Navarra

e-mail: mkinateder@unav.es

Hubert János Kiss

research fellow

Momentum Game Theory Research Group

Institute of Economics - Centre for Economic and Regional Studies

Hungarian Academy of Sciences

and Department of Economics, Eötvös Loránd University

e-mail: kiss.hubert.janos@krtk.mta.hu

Ágnes Pintér

ayudante doctor

Department of Economic Analysis, Universidad Autónoma de Madrid, e-mail: pinteragnes@gmail.com

October 2015

ISBN 978-615-5594-20-5

ISSN $1785377 \mathrm{X}$ 


\title{
Would depositors like to show others that they do not withdraw? Theory and Experiment
}

\author{
Markus Kinateder - Hubert János Kiss - Ágnes Pintér
}

\begin{abstract}
There is an asymmetry regarding what previous decisions depositors may observe when choosing whether to withdraw or keep the money deposited: it is more likely that withdrawals are observed. We study how decision-making changes if depositors are able to make their decision to keep their funds in the bank visible to subsequent depositors at a cost. We show theoretically in a Diamond-Dybvig setup that without this signaling option multiple equilibria are possible, while signaling makes the no-run outcome the unique equilibrium. We test if the theoretical predicitions hold in a lab experiment. We find that indeed when signaling is available, bank runs are less likely to arise and signaling is extensively used.
\end{abstract}

Keywords: Bank runs, Asymmetric information, Experimental evidence, Signaling

JEL classification: C72, C91, D80, G21 


\title{
Szeretnék a betétesek, ha a többiek tudnák, hogy nem veszik ki a pénzüket? Elmélet és kísérlet
}

\author{
Markus Kinateder - Kiss Hubert János - Pintér Ágnes
}

\section{Összefoglaló}

Aszimmetria áll fenn azt illetően, hogy milyen korábbi döntéseket figyelhetnek meg a betétesek: valószínúbb, hogy pénzkivéteket láthatnak. Azt vizsgáljuk, hogy változik-e és hogyan a döntéshozatal, ha a betétesek költséges módon láthatóvá tehetik a később döntő betétesek számára, hogy bennhagyják a bankban a pénzüket. A Diamond-Dybvig-modell keretein belül elméletileg megmutatjuk, hogy ezen lehetőség nélküli több egyensúly (köztük bankroham) lehetséges, azonban a lehetőség megteremtésével megszűnnek a bankroham kimenetelek. Az elméleti predikciókat laboratóriumi kísérletben teszteljük. Azt találjuk, hogy amikor a jelzési lehetőség rendelkezésre áll, akkor kisebb valószínűséggel következik be bankroham és a kísérleti alanyok a jelzést gyakran használják.

Tárgyszavak: bankroham, aszimmetrikus információ, kísérlet, jelzés

JEL kód: C72, C91, D80, G21 


\title{
Would depositors like to show others that they do not withdraw? Theory and Experiment
}

\author{
Markus Kinateder, \\ Universidad de Navarra* \\ Hubert János Kiss, \\ Eötvös Loránd University and MTA KRTK ${ }^{\dagger}$ \\ Ágnes Pintér \\ Universidad Autónoma de Madrid ${ }^{\ddagger}$
}

26 October 2015

\begin{abstract}
There is an asymmetry regarding what previous decisions depositors may observe when choosing whether to withdraw or keep the money deposited: it is more likely that withdrawals are observed. We
\end{abstract}

*Departamento de Economía, Edificio de Amigos, Universidad de Navarra, 31009 Pamplona, Spain. E-mail: mkinateder@unav.es. Phone: +34-948-425 600 ext. 802787.

†Department of Economics, Eötvös Loránd University, 1117 Pázmány sétány 1/a, Budapest, Hungary. E-mail: hubert.kiss@tatk.elte.hu. Phone: +36-30-4938062. Kiss is also a research fellow in the "Momentum" (LD-004/2010) Game Theory Research Group at MTA KRTK.

${ }_{\ddagger}^{\ddagger}$ Department of Economic Analysis, Universidad Autónoma de Madrid, 28049, Cantoblanco, Madrid, Spain. E-mail: pinteragnes@gmail.com. 
study how decision-making changes if depositors are able to make their decision to keep their funds in the bank visible to subsequent depositors at a cost. We show theoretically in a Diamond-Dybvig setup that without this signaling option multiple equilibria are possible, while signaling makes the no-run outcome the unique equilibrium. We test if the theoretical predicitions hold in a lab experiment. We find that indeed when signaling is available, bank runs are less likely to arise and signaling is extensively used.

JEL classification numbers: C72, C91, D80, G21

Keywords: Bank runs, Asymmetric information, Experimental evidence, Signaling

\section{Introduction}

The run on Northern Rock, an English bank, heralded the onset of the financial crisis during which episodes of banks and other financial institutions suffering sudden and massive withdrawals of deposits and other funding sources were frequent (e.g. the investment bank Bear Stearns in the US, the DSB Bank in the Netherlands or Bankia in Spain). Deteriorating fundamentals are a prime cause of bank runs, but there was often also a substantial selffulfilling component to the behavior of depositors. Depositors may just hurry to withdraw fearing that other depositors will do so and if they go late no funds may be left in the bank. This fear is illustrated vividly by the words of Anne Burke, a client of Northern Rock, who said the following while queuing up to withdraw her funds: "It's not that I disbelieve Northern Rock, but everyone is worried and I don't want to be the last one in the queue. If everyone else does it, it becomes the right thing to do." 1 The above quote shows that depositors react to other depositors' observed decisions. Empirical studies (Kelly and O Grada, 2000; Starr and Yilmaz, 2007; and Iyer and

\footnotetext{
${ }^{1}$ See http://www.bloomberg.com/apps/news?pid=newsarchive\&sid=aeypCkzcRlU4
} 
Puri, 2012) and experimental findings (Garratt and Keister, 2009; Kiss et al. 2012) support this idea as well.

Depositors' decision may be seen as a coordination game in which observing other depositors' decisions is important. Therefore, it is relevant to know what can be observed? In the seminal paper by Diamond and Dybvig (1983) it is assumed that depositors play a simultaneous-move game, so no decision can be observed. This setup yields two symmetric equilibria: i) bank run, when everybody rushes to withdraw from the bank, ii) no bank run, when only those withdraw who need liquidity. This model applies well to some cases in reality, when observability of other depositors' actions is almost non-existent. It was the case during the silent run on Washington Mutual in 2008, when depositors withdrew their funds electronically. ${ }^{2}$ Other empirical observations suggest however, that both withdrawal and the decision to keep the money deposited are observable. Kelly and O Grada (2000) and Iyer and Puri (2012) point at the importance of observing decisions of both sorts in one's social network. In Starr and Yilmaz (2007), small and medium-sized depositors observe only withdrawals of their peers during a bank run incident in 2001 in Turkey, but the behavior of large depositors appears to be driven by observing both choices. However, these empirical studies suggest that observing that somebody has decided to keep her funds in the bank is restricted to one's social network or a limited set of depositors, while withdrawals are more broadly observed. When seeing the queues in front of the bank we know that the people in the queue decided to withdraw. But we do not know if those who are not in the line have decided to keep the money in the bank or have not decided yet (and potentially will decide to withdraw). Hence, there seems to be an asymmetry in the observability of depositors' decision, withdrawal being more visible.

Is the previous asymmetry important? Empirical papers and experimen-

\footnotetext{
${ }^{2}$ When nothing is observed, Arifovic et al. (2013) show experimentally that bank runs are more likely the more stringent are the conditions for the coordination of depositors.
} 
tal studies suggest that the answer is positive. Kelly and O Grada (2000) find that the county of origin is the prime determinant of the depositors' decision and it is due to the fact that people coming from the same county tended to live in the same neighborhood. In some neighborhood depositors ran, while in others they did not. Hence, observing withdrawals makes bank runs more likely, while if depositors observe that others have kept their money deposited, then they are more likely to follow suit. Kiss et al. (2014) find experimentally that - compared to observing nothing - observing a withdrawal (keeping the money deposited) increases (decreases) the likelihood of withdrawal. These results suggests that if depositors could make visible their choice to keep their funds deposited, then bank runs would be less likely to occur. We study theoretically and experimentally if this conjecture is correct.

We claim that bank runs in the Diamond-Dybvig model may be prevented by enhancing the observability of depositors' actions, especially if the decision to keep the money deposited is made visible. Following Diamond and Dybvig (1983), bank-run models generally use a simultaneous-move framework, implying that depositors do not observe any decisions. Nevertheless, banks are able to observe to some extent depositors' decisions. Peck and Shell (2003) claim that the most natural assumption is that only withdrawals are observed by the bank, since depositors do not go to the bank to tell that they do not want to withdraw. Green and Lin (2000, 2003) assume that each depositor contacts the bank and communicates her decision of withdrawal or keeping the money deposited. We combine these two views and suppose that withdrawals are observable, whereas keeping the money deposited is not. ${ }^{3}$ However, assume that holdings can be made observable, at a cost. Thus, a depositor who decides to hold can send a signal to the bank that reveals her decision. Important for our purpose, the bank upon observing the decision of a depositor communicates it to those who have not decided yet.

In our model, depositors decide in a consecutive way according to an ex-

\footnotetext{
${ }^{3}$ We use "keeping the money deposited" and "holding" in an interchangeable manner.
} 
ogenously given sequence of decisions. ${ }^{4}$ Each depositor can either withdraw, hold and signal or hold without signaling. Sending the signal is costly, but a signal of holding may induce subsequent patient depositors to hold as well. We show that as the game unfolds, for any patient depositor signaling strictly dominates withdrawal. As a consequence, patient depositors know that no other patient depositor would withdraw given the information sets that may arise, so they choose to hold without signaling. Therefore, the unconstrainedefficient allocation is implemented without costs. The intuition behind the result is that signaling is needed to make withdrawal a strictly dominated action, but once it is strictly dominated signaling becomes strictly dominated as well.

Our assumption about signaling the decision of holding fits into the existing literature of bank runs, as explained before. Signaling - as seen in this paper - is not a standard practice in financial intermediation. However, with recent technological advances it may not just be a theoretical instrument but a practical one in the future. Signaling can also be seen as a metaphor of intense communication between the bank and its depositors.

We test the theoretical results experimentally as well in the lab. We find suggestive evidence of a treatment effect. Notably, the probability of bank runs is considerably lower in the treatment given all possible sequences of decisions. Individual decisions reveal only moderate differences at the coinciding different information sets. However, participants in the treatment with signaling use extensively the costly signals and it leads to a decrease of withdrawals and, as a consequence, of bank runs. Hence, the experiment confirms that there is a difference in terms of withdrawals between treatments as predicted by theory. However, contrary to the theoretical prediction signaling is often observed.

\footnotetext{
${ }^{4}$ This assumption is usual in the literature. See Green and Lin (2000, 2003), Andolfatto et al. (2007) or Ennis and Keister (2009b).
} 


\subsection{Related literature}

Most theoretical papers assume that depositors make the decision about withdrawal of funds simultaneously (e.g. Diamond and Dybvig, 1983; Ennis and Keister, 2009). Ennis and Keister (2015) study a setup that features aggregate uncertainty regarding the type of depositors. The bank and depositors observe withdrawals as they occur and they show that bank runs may arise in such an environment..Kinateder and Kiss (2014) who suppose that depositors decide after each other according to a predetermined order (line) and they observe all previous choices before making decision. They study two setups: when, besides actions, liquidity needs of previous depositors are also observed, and when only the previous actions are observed and liquidity needs are private information. In both cases, they obtain that bank runs do not occur in equilibrium.

Related to our idea, we are aware of two papers that eliminate bank runs through enriching the set of actions and the information in the underlying game. Cavalcanti and Monteiro (2015) and Andolfatto et al. (2014) have models with aggregate uncertainty about types. The idea behind Cavalcanti and Monteiro (2015) is that patient depositors who withdraw do not mind to reveal that they lied once they received their money and if they reveal it then the bank can always use the correct conditional distributions to assign payments to the subsequent depositors. The fact that the bank is able to adjust payments quickly leads to the elimination of the run strategy. Andolfatto et al. (2014) augments the announcement space and depositors can announce also if they believe that a bank run is underway. Under threat of suspension conditional on the communication run equilibria are eliminated. Our paper is connected to these papers as we also assume that the canonical choice set of waiting and withdrawal is augmented with the possibility of waiting and making it public at a cost. However, there are noticeable differences. While elimination of the bank run equilibrium in the other papers is based on the bank's ability to detect quickly that a bank run is on, our result builds on 
observability and the bank does not need to adjust payments. This difference is due to large extent to the existence of aggregate uncertainty about liquidity types in Cavalcanti and Monteiro (2015) and Andolfatto et al. (2014), because there the question is whether the bank is able to recognize in time that there is a bank run and the large number of withdrawals is not due to a liquidity shock. In contrast, in our classic Diamond-Dybvig setup there is no such aggregate uncertainty and bank runs arise if patient depositors believe that many other patient depositors will withdraw. By making observability of non-withdrawal possible, we may eliminate such beliefs and remove bank run equilibrium.

In experiments investigating bank runs, mainly simultaneous decisions have been considered to study the problem of coordination among depositors (e.g., Arifovic, Jiang and Xu, 2013) or analyze if bank runs can be contagious (Brown, Trautmann and Vlahu, 2012). There are only few experiments that allow for the observability of previous decisions. ${ }^{5}$ Schotter and Yorulmazer (2009) claim that sequentiality is an important element in bank runs. In their experiment they use simultaneous and sequential treatments, being the first to compare outcomes when the degree of observability differs. They study how different factors (e.g. asymmetric information, deposit insurance) affect the speed of withdrawals. ${ }^{6}$ Theoretically, subjects' behavior should not depend on the form of the game, but Schotter and Yorulmazer (2009) show that the available information (e.g. about past decisions) affects the subjects' choices. In contrast to their results, we obtain our findings in an environment without uncertainty about the fundamentals of the bank. ${ }^{7}$

\footnotetext{
${ }^{5}$ In Brown, Trautmann and Vlahu (2012) depositors of the same bank decide simultaneously, but depositors may observe the decisions of depositors of other banks.

${ }^{6}$ Kiss, Rodriguez-Lara and Rosa-Garcia (2012a) and Madies (2006) also investigate the efficiency of deposit insurance to curb bank runs by means of laboratory experiments.

${ }^{7}$ In Schotter and Yorulmazer (2009) uncertainty involves the fundamentals of the bank, since banks have different quality that is generally unobservable to depositors. Chari and Jagganathan (1988) show theoretically how a heightened withdrawal demand may be perceived incorrectly as a signal that the bank's quality is poor.
} 
Garratt and Keister (2009) introduce two novel elements: in some treatments subjects were given up to three opportunities of withdrawal and sometimes faced forced withdrawals. In the treatment with multiple opportunities to withdraw subjects were informed about the total number of withdrawals in their bank after each opportunity. Forced withdrawals occurred with some probability as some subjects were forced to withdraw; and the other subjects observed these forced withdrawals. Garratt and Keister (2009) show that uncertain withdrawal demand when subjects have multiple opportunities to withdraw result in frequent bank runs. Interestingly, these factors alone do not lead to a large number of bank runs. They claim that more information about other depositors' decisions may be harmful for coordination when there are still opportunities to withdraw. We note that none of these papers considers the asymmetry of available information.

At the heart of the paper lies the assumption that a patient depositor is able to reveal in a credible way that she will keep her funds deposited. The closest mechanism in real life is to commit not to withdraw the funds by having a time deposit instead of a sight deposit. Niinimaki (2002) proposes a model that has time deposits and is able to prevent bank runs. However, there observability does not play any role.

Making visible that people keep their money deposited was also present in banking panic episodes. Bruner and Carr (2008) describe how JP Morgan and his associates tried to deal with the 1907 panic in New York. A centerpiece of their action was to reassure the public that there was no need to panick. Each possible clergyman, priest and rabbi was visited by the associates and asked to make comforting statements to their congregations We may interpret this effort as a way to make visible that a leader of the community will not withdraw and potentially those who hear the sermons will follow suit.

The paper is organized as follows. Section 2 introduces notation and defines the model. In section 3, we derive the theoretical results. Section 4 lays out the experimental procedure and presents the findings. Section 5 
concludes.

\section{The model}

There are two time periods denoted by $t=1,2$, and a finite set of depositors denoted by $I=\{1, \ldots, N\}$, where $N>2$. The consumption of depositor $i \in I$ in period $t=1,2$ is denoted by $c_{t, i} \in \mathbb{R}_{+}^{0}$. Her liquidity type is denoted by $\theta_{i}$ and belongs to the set of liquidity types $\Theta=\{1,2\}$. If $\theta_{i}=1$, depositor $i$ is called impatient, that is, she only cares about consumption at $t=1$. If $\theta_{i}=2$, depositor $i$ is called patient. Given $\theta_{i} \in\{1,2\}$, each depositor $i$ 's utility function is given by

$$
u_{i}\left(c_{1, i}, c_{2, i}, \theta_{i}\right)=u_{i}\left(c_{1, i}+\left(\theta_{i}-1\right) c_{2, i}\right)
$$

It is assumed to be strictly increasing, strictly concave, twice continuously differentiable and to satisfy the Inada conditions. The relative risk-aversion coefficient, $-c_{i} u_{i}^{\prime \prime}\left(c_{i}\right) / u_{i}^{\prime}\left(c_{i}\right)$, is assumed to be strictly larger than 1 , for all $c_{i} \in \mathbb{R}_{+}$, and all $i \in I$.

Each depositor has one unit of a homogeneous good deposited in the bank. The bank has access to a constant-return-to-scale productive technology which pays a gross return of one unit for each endowment liquidated at $t=1$, and a fixed return of $R>1$ for each endowment liquidated at $t=2 .^{8}$ It offers a simple demand deposit contract which pays $c_{1}^{*}$ to any depositor $i$ who withdraws at $t=1$, as long as the bank has funds left, and the same pro rata share of funds available to all depositors who wait until $t=2$.

The number of patient depositors is assumed to be constant and given by $p \in\{1, \ldots, N\}$ and the remaining depositors are impatient. The number of patient and impatient depositors is common knowledge. However, each depositor's type is only realized at $t=1$.

\footnotetext{
${ }^{8}$ We follow the literature (Diamond and Dybvig, 1983; Green and Lin, 2003; Ennis and Keister, 2009a and 2014) assuming there is no fundamental uncertainty about the return.
} 
Let $\Theta^{N}=\{1,2\}^{N}$, and $\theta^{N}=\left(\theta_{1}, \ldots, \theta_{N}\right)$ denote the sequence of depositors, also called (liquidity) type vector. The set of sequences of length $N$ with $p$ patient depositors is given by

$$
\Theta^{N, p}=\left\{\theta^{N} \in \Theta^{N}: \sum_{i=1}^{N}\left(\theta_{i}-1\right)=p\right\} .
$$

There are $\left(\begin{array}{l}N \\ p\end{array}\right)$ possible type vectors. At $t=1$, one is selected randomly by a process which selects each of them with equal probability. Under imperfect information, the realized liquidity type vector is unobserved both by the depositors and the bank.

Next, the Pareto efficient allocation is derived. A social planner could maximize the sum of depositors' utilities (which are assumed to be identical, except of the liquidity type) with respect to $c_{1, i}$ and $c_{2, i}$ subject to a resource constraint and to the commonly known number of patient and impatient depositors, $p$ and $N-p$, respectively. The first best allocation solves

$$
\begin{gathered}
\max _{c_{1, i}, c_{2, i}}(N-p) u_{i}\left(c_{1, i}\right)+p u_{i}\left(c_{2, i}\right) \\
\text { s. t. }(N-p) c_{1, i}+\frac{p}{R} c_{2, i}=N .
\end{gathered}
$$

The solution to this problem is

$$
u^{\prime}\left(c_{1}^{*}\right)=R u^{\prime}\left(c_{2}^{*}\right),
$$

which, as in Diamond and Dybvig (1983), implies that $R>c_{2}^{*}>c_{1}^{*}>1$. In the first best allocation, all impatient depositors consume $c_{1}^{*}$ at $t=1$, and all patient ones $c_{2}^{*}$ at $t=2$. Hence, patient depositors receive a higher consumption than impatient ones.

\subsection{Strategies and equilibrium concept}

A sequential service constraint is assumed to hold, that is, at $t=1$, the depositors contact the bank sequentially in the order given by $\theta^{N}$, and the 
payment to any withdrawing depositor only depends on the history, but not on the decisions of subsequent depositors, as will be specified below.

Once it is depositor $i$ 's turn to decide, she decides whether to wait or withdraw, that is, she chooses an element in $\Theta$ such that 1 implies withdraw and 2 wait. Moreover, she decides whether to send a costly signal that publicly reveals her decision or not. Denote the signal space by $\Sigma \equiv\{s g, n s g\}$, that is, a depositor decides whether to send a signal, denoted by $s g$, or not, denoted by $n s g$. Let $\Sigma^{N}=\{s g, n s g\}^{N}$.

Since withdrawals are publicly observable by all other depositors as well as the bank, it will be a strictly dominated strategy for depositor $i$ to choose $s g$ in case she withdraws since this is costly for her. For a depositor who decides to wait, however, the equilibrium analysis will determine whether this is true as well.

Depositor $i$ 's strategy is then defined as $\mathbf{s}_{i} \in \Theta \times \Sigma$, though, for the reason just mentioned, $\mathbf{s}_{i}$ will always be an element in $\{1,2 s g, 2 n s g\}$; that is, she announces a type from $\Theta$ and if she waits whether to costly signal this or not. When type 1 or 2 is announced, she wishes to consume at $t=1$ (i.e., withdraw) or at $t=2$ (i.e., wait), respectively; and when $s g$ or $n s g$ is announced, she sends a costly signal publicly revealing her decision or not, respectively.

The bank and each depositor $i$ are assumed to observe withdrawals and signals perfectly. When it is depositor $i$ 's turn to decide, she observes the history of all withdrawals and signals sent by waiting depositors: let $h_{i}^{t}$ denote the history observed by depositor $i$ that contains $t$ observations of signals and withdrawals. $^{9}$

Anonymity is assumed, that is, depositor $i$ 's index does not reveal any information about her position in the queue. However, observing $h_{i}^{t}, i$ knows that her position in the queue $\theta^{N}$ is at least $t$, though she could be at a later

\footnotetext{
${ }^{9}$ Note that to wait and signal withdrawal or to withdraw and signal wait is immediately identified as erroneous by the other depositors, and thus, we do not consider this kind of strategic behavior.
} 
position if some depositor before her decided to wait, but not to signal this.

Depositor $i$ 's strategy is conditional on the history she observed and her type. Given this, and following Ennis and Keister (2014), it is formally defined as $\mathbf{s}_{i}: \Theta \times \boldsymbol{\Theta}^{N} \times \Sigma^{N} \rightarrow \Theta \times \Sigma .^{10}$

Slightly abusing notation, let $\mathbf{S}=\{1,2 s g, 2 n s g\}^{N}$ be the game's strategy space, and let $\mathbf{s} \in \mathbf{S}$ be a strategy profile, that is, $\mathbf{s}=\left(\mathbf{s}_{1}, \ldots, \mathbf{s}_{N}\right)$. In order to emphasize depositor $i$ 's strategy, $\mathbf{s}$ is sometimes written as $\left(\mathbf{s}_{i}, \mathbf{s}_{-i}\right)$.

Given strategy profile $\mathbf{s} \in \mathbf{S}$, depositor $i$ 's consumption is specified by $c_{i}=\left(c_{1, i} ; c_{2, i}\right)$, where $c_{1, i}: \boldsymbol{\Theta}^{i} \rightarrow \mathbb{R}_{+}^{0}$, and $c_{2, i}: \boldsymbol{\Theta}^{N} \rightarrow \mathbb{R}_{+}^{0}$. The consumption of all depositors is feasible if $\sum_{i=1}^{N}\left(c_{1, i}+\frac{c_{2, i}}{R}\right) \leq N$. Depositor $i$ 's period-1 consumption is then defined as

$$
c_{1, i}= \begin{cases}c_{1}^{*}, & \text { if } s_{i}=1 \text { and } N-\sum_{j=1}^{i-1}\left(2-s_{j}\right) c_{1}^{*} \geq c_{1}^{*}, \\ y, & \text { if } s_{i}=1 \text { and } 0<N-\sum_{j=1}^{i-1}\left(2-s_{j}\right) c_{1}^{*}<c_{1}^{*}, \\ 0, & \text { otherwise }\end{cases}
$$

where $y=N-\sum_{j=1}^{i-1}\left(2-s_{j}\right) c_{1}^{*}:$ until the bank runs out of funds, any depositor who announces to be impatient receives a positive consumption $c_{1}^{*}$ or $y$.

Let $\eta \in\{0, \ldots, p\}$ be the number of depositors who wait at $t=1$, that is, each of them announces to be of type $2 .{ }^{11}$ Given $\eta=\frac{1}{2} \sum_{i=1}^{N} s_{i} \geq 0$, all players who wait at $t=1$, obtain the same consumption at $t=2$, namely,

$$
c_{2}(\eta)=\max \left\{0, \frac{R\left(N-(N-\eta) c_{1}^{*}\right)}{\eta}\right\}
$$

If $\eta=p$, only impatient depositors withdraw at $t=1$, and $c_{2}(\eta)=c_{2}^{*}>c_{1}^{*}$. Then, patient depositors enjoy a higher consumption than impatient ones.

\footnotetext{
${ }^{10}$ Given a history of length $t$, player $i$ takes into account all possible paths in the corresponding extensive form game which yield this history. As will become clear later, there are histories after which $i$ is for sure at one of the earlier positions in the queue, and others, after which she is for sure at a later position in the queue.

${ }^{11}$ Note that $\eta$ is restricted to be equal to $p$ or smaller since an impatient depositor has a dominant strategy to withdraw, and thus, not more than $p$ depositors will wait.
} 
If depositor $i$ chooses to signal that she waits, then she is charged an additional small cost of $\xi>0$ in terms of her utility such that $u_{i}\left(c_{2, i}^{*}\right)-\xi>$ $u_{i}\left(c_{1, i}^{*}\right)$. Thus, the strategy profile determines a depositor's consumption in both periods and whether she sends a signal or not. Both in turn determine her utility: for any $i \in I$, and any $\mathbf{s} \in \mathbf{S}$, this is denoted by $u_{i}(\mathbf{s})$. Thus, $u_{i}$ is a mapping from $\mathbf{S}$ to $[-\xi, \infty)$. Let the tuple $(I, \mathbf{S}, u)$ be the bank run game, where $u=\left(u_{1}, \ldots, u_{N}\right)$.

Depositor $i$ observes $h_{i}^{t}$, knows her type $\theta_{i}$ and the commonly known parameters $p$ and $N$. However, due to imperfect information, she does not know her position in the queue and neither observes the realized type vector. Given the available information, she forms beliefs about her position in the queue and about the type vector that was selected by nature. Let $\mu_{i} \equiv$ $\mu_{i}\left(\theta^{N} \mid h_{i}^{t}, \theta_{i}\right)$ denote depositor $i$ 's belief about the type vector. This belief is conditional on the history and $i$ 's type and is updated according to Bayes' rule whenever possible. The belief together with a strategy profile defines a Perfect Bayesian Equilibrium.

Definition 1. Given a bank run game. Then, strategy profile $\mathbf{s} \in \mathbf{S}$ and belief system $\mu=\left(\mu_{1}, \ldots \mu_{N}\right)$ are a Perfect Bayesian Equilibrium (PBE) if, and only if, for all $i \in I$, given $\theta_{i}, h_{i}^{t}$ and any $\tilde{\mathbf{s}}_{i} \in\{1,2\}$,

$$
\sum_{\theta^{N} \in \Theta^{N}} \mu_{i}\left(\theta^{N} \mid h_{i}^{t}, \theta_{i}\right) u_{i}(\mathbf{s}) \geq \sum_{\theta^{N} \in \Theta^{N}} \mu_{i}\left(\theta^{N} \mid h_{i}^{t}, \theta_{i}\right) u_{i}\left(\tilde{\mathbf{s}}_{i}, \mathbf{s}_{-i}\right),
$$

where $\mu_{i}\left(\theta^{N} \mid h_{i}^{t}, \theta_{i}\right)$ is consistent with Bayes' rule whenever possible.

A strategy profile and belief system are a PBE if, and only if, the strategy is sequentially rational given the belief for all players and the belief is consistent with the strategy (see Fudenberg and Tirole, 1991, and Myerson, 1997). Moreover, there are consistency requirements on the beliefs that arise from the fact that $p$ and $N$ are commonly known, the history is commonly observed and an impatient depositor's dominant strategy is to withdraw. These are discussed in more depth below. 


\section{Theoretical results}

The simple demand deposit contract defined above yields the Pareto efficient allocation (see Diamond and Dybvig, 1983). Our goal is to show that this allocation is the unique PBE outcome of the bank run game.

Given $p, N$ and $c_{1}^{*}$, it is possible to determine how many patient depositors have to wait in order for waiting to be an optimal strategy for each of them. In Lemma 1, one part of this threshold is derived, ${ }^{12}$ namely, the one (denoted as $\bar{\eta}$ ) such that $c_{2, i}>c_{1}^{*}$, for every patient depositor $i$ who waits at $t=1$. If some patient depositor declares to be impatient, then the bank spends funds on her which it would otherwise have kept until $t=2$. Recall that $\eta$ is the number of patient depositors that wait.

Lemma 1. Given $p, N$ and $c_{1}^{*}$, there is a unique $\bar{\eta}$ such that $1 \leq \bar{\eta} \leq p$, and for every patient depositor $i$ for whom $\mathbf{s}_{i}=2, c_{2, i}(\eta) \leq c_{1}^{*}$, for all $\eta \leq \bar{\eta}$, and $c_{2, i}(\eta)>c_{1}^{*}$, for all $\eta>\bar{\eta}$.

The proof of Lemma 1 follows as a corollary from Kinateder and Kiss (2014).

This result also yields the minimum number of withdrawals that need to be observed in order for withdrawing to be a dominant strategy at $t=1$ for any depositor since more than $N-p$ depositors withdrew already.

\subsection{Example}

The depositors commonly know $p$ and $N$, and that nature selects each type vector with equal probability. Moreover, each depositor knows her own type and observes the history. This is referred to as available information. Given the available information, a depositor forms beliefs about the type vector selected by nature and, by sequential rationality, anticipates how subsequent

\footnotetext{
${ }^{12}$ The other part is a technical detail which is derived below in Proposition 1's proof.
} 
depositors behave. In such an environment of imperfect information, sequential rationality plays a similar role as backward induction in games of perfect information (see Myerson, 1997).

Suppose that there are four depositors: one is impatient and the other three are patient. Before the game begins, nature selects each of the four possible type vectors with equal probability. Once the type vector is selected, each depositor observes her type but not any other's and neither her position in the queue. Then, they take decisions in a sequential order. Moreover, we make the following assumption.

Assumption 1. All three patient depositors have to keep the money in the bank in order to make waiting worthwhile for all of them.

We take the utility function from Ennis and Keister (2009). For all $i$, it is defined as

$$
u_{i}=\frac{c_{1}^{1-\delta}}{1-\delta}+\left(\theta_{i}-1\right) \frac{c_{2}^{1-\delta}}{1-\delta}
$$

It fulfils the assumptions made in section 1. In particular, let $R=1.25$ and $\delta=3$ be the risk aversion coefficient. The optimal allocation is $c_{1}^{*}=1.116$ and $c_{2}^{*}=1.202$. Then, it is easy to calculate that after two withdrawals 2.232 of the 4 units deposited in the bank are gone and any remaining depositor is strictly better off to withdraw the remaining funds of 1.768 at $t=1$ rather than to wait: if two depositors wait, then at $t=2$, the total funds left are 2.21 which yields $1.105<1.116$ for each of them. So any subsequent depositor is better off to withdraw, and therefore, this example fulfils Assumption 1.

Obviously, any impatient depositor $i$ is always strictly better off to withdraw since $\theta_{i}=1$ for her. So any candidate strategy profile which contains such a case is never a PBE. In all remaining cases, the impatient depositor withdraws, while the patient depositors withdraw, wait, wait and signal or choose different actions. Taking this into account, the following list of strategy profiles is a complete description of all possible equilibrium candidate 
strategy profiles that can arise given the set of depositors, their types and strategies as well as that the impatient depositor withdraws:

- Pooling equilibrium candidate: all depositors choose the same action, that is, withdraw.

- Separating equilibrium candidate: all depositors of one type choose the same action, and that of the other type another action; that is, the impatient depositor withdraws, the patient ones either all wait or wait and signal.

- Any other equilibrium candidate: the impatient depositor withdraws, there are at least two patient depositors that choose different actions.

Deriving the PBE Now we will go through the three candidate strategy profiles that are left. Consider first the separating PBE candidate: independently of the realized type vector, on the equilibrium path, all patient depositors either wait or wait and signal, while the single impatient depositor withdraws.

It is quite easy to see that to wait and signal for the three patient depositors is no PBE since the last patient depositor in the queue (after observing two signals of waiting) is strictly better off to save the signal cost and to wait. So she has a profitable deviation and this is no PBE.

We show next that the separating PBE candidate in which the impatient depositor withdraws and the three patient ones wait is a PBE. Obviously, the impatient depositor's strictly dominant strategy is to withdraw and she has no profitable deviation to wait or to wait and signal. ${ }^{13}$ Her strategy is optimal after any history and given any belief. On the equilibrium path, her belief assigns a probability of $\frac{1}{4}$ to each type vector in which she occupies one of the four positions, that is, the cannot update her belief from the prior.

\footnotetext{
${ }^{13}$ Though on an off-equilibrium path on which the bank ran out of funds she is indifferent to wait or not since her utility is 0 anyway, and thus, her strategy is not strictly dominant.
} 
On an off-equilibrium path, her belief is derived analogously to the one of the corresponding patient depositor after observing the history, though taking into account that she is impatient.

Patient depositors: Consider now a patient depositor's complete strategy and belief system for the four possible positions she can have taking into account that she only observes the history, but does not know her position in the queue. Her complete strategy is to wait as long as the history contains at most one withdrawal and to withdraw otherwise.

Depositor 1: she observes an empty history which is compatible with being on the equilibrium path. She puts an equal belief on the type vector in which she is in the first, second or third position and the impatient depositor is behind her; if the impatient depositor were before her, then she would have observed a withdrawal. By sequential rationality, she anticipates that the two remaining patient depositors will wait or waited already before her and that the impatient depositor (behind her) will withdraw. She has no profitable deviation from waiting since both withdrawing or waiting and signaling yield her a lower expected payoff. Thus, it is optimal for her to wait.

Depositor 2: suppose first that she observes an empty history. Then, her reasoning is identical to depositor 1's and her optimal decision is to wait. Suppose next that she observes a withdrawal. Then, her reasoning is identical as before with the sole exception that she is now sure that the impatient depositor is before her in the queue, that is, she believes to occupy position 2, 3 or 4, each with equal probability. Again her optimal decision is to wait and she has no profitable deviation.

Finally, suppose that she observes any other off-equilibrium path history. Given that she is in the second position the only history left that she could observe is a signal of waiting. Then, while she finds herself on an off-equilibrium path, her reasoning is identical as before and her optimal decision is to wait given that she didn't observe more than one withdrawal. (Her belief assigns a probability of $\frac{1}{3}$ each to her and the impatient depositor being in positions 
$(2,3),(3,4),(2,4)$, respectively.)

Depositor 3: the reasoning for her is identical as for depositor 2 if she either observes the empty history, one withdrawal or one waiting and signal.

Consider now the history in which she observes two withdrawals: then, her optimal decision is to withdraw and she complies with her strategy (independently of her belief). To wait or to wait and signal are no profitable deviations in this case. Her belief assigns an equal probability to the cases in which she is at position 3 and two depositors before her withdrew or she is the last depositor and depositors 2 and 3 withdrew, while depositor 1 waited.

In any other case, an out off equilibrium path history contains at most one withdrawal. Therefore, she is better off to wait and has no profitable deviation. Her belief is obtained accordingly.

Depositor 4: on the equilibrium path she observes one withdrawal and applies an identical reasoning as the other patient depositors in this case. She is better off to wait rather than to withdraw or to wait and signal. She believes with equal probability to be in position 2,3 or 4 .

The out off equilibrium behavior is covered by the cases of the other depositors. If the history contains two withdrawals, then she is strictly better off to withdraw and if there were three withdrawals, then the bank is bankrupt already. Otherwise, she is strictly better off to wait forming corresponding beliefs.

Given this strategy, any depositor's decision on the equilibrium path is optimal and no bank run is a PBE.

On the equilibrium path, any other belief system is not consistent with the strategy profile and the available information. However, on some offequilibrium path, while the depositors' strategies are optimal given the observed history, their belief updating is unconstrained and there are possibly other consistent beliefs. Hence, there are multiple PBE strategy profiles which differ by depositors' beliefs and strategies off the equilibrium path. Yet, given any consistent belief system, the strategy profile is a PBE and yields no bank 
run as outcome.

Uniqueness of PBE outcome In order to show that there is a unique PBE outcome, it is left to show that the pooling equilibrium candidate and any other equilibrium candidate are no PBE.

That the pooling equilibrium candidate in which all three patient depositors withdraw is no PBE follows from the example in Kinateder and Kiss (2014). Suppose that nature selects a type vector in which a patient depositor is first in the queue. Then, she observes an empty history and believes to be the first depositor in the queue. She has a profitable deviation to wait and signal this. Then, analogously as in Kinateder and Kiss (2014), the other patient depositors in the queue after observing this signal are better off to wait on this out of equilibrium path. Hence, there is no bank run and this strategy profile is no $\mathrm{PBE}$.

Consider next any remaining strategy profile. In this case, the impatient depositor withdraws and there are at least two patient depositors choosing different actions. We will now consider all possible cases.

Suppose that each patient depositor chooses a different action. Then, since there overall two withdrawals (one by the impatient and another by a patient depositor), a bank run occurs for sure. Therefore, there is a type vector in which each of the two patient depositors that do not withdraw has a profitable deviation to do so and this is no PBE.

Suppose next that some patient depositor is asked to withdraw and some other to wait. Then, if there is one patient depositor who is asked to withdraw, she has a profitable deviation to wait as well since then there is no bank run and she receives a higher payoff. Similarly, if there are two patient depositors asked to withdraw and one to wait, then the one who is prescribed to wait has a profitable deviation to withdraw in any type vector in which she is in the one of the first three positions. Thus, both types of strategy profiles are no PBE. 
Analogously, it follows immediately from the previous argument that any strategy profile in which some patient depositor is asked to withdraw and some to wait and signal is no PBE either.

Finally, consider any strategy profile in which some patient depositor is asked to wait and some other to wait and signal. Then, the one who is asked to send a signal can save the corresponding cost and wait nevertheless. Thus, she has a profitable deviation and this is no PBE either. In this way, we considered all possible strategy profiles, and after showing that a bank run is never a PBE outcome, it follows that no bank run is the unique PBE outcome.

\subsection{The general case}

The arguments in the previous subsection are generalized in order to find the set of PBE for any bank run game and the unique PBE outcome is no bank run which is the Pareto efficient allocation.

Proposition 1. Given a bank run game, then the Pareto efficient allocation is the unique PBE outcome.

The proof of Proposition 1 can be found in Appendix A. Intuitively, in any PBE, given the available information, it is consistent for a patient depositor to believe to be on the equilibrium path as long as there are $N-p$ or less withdrawals, that is, unless she observes a history which is incompatible with being on the equilibrium path. Given this belief, it obviously yields her a higher expected utility to wait. She waits and anticipates, by sequential rationality, that all other patient depositors behind her will wait as well. For each of them, an analogous reasoning applies and it is optimal to wait. This in turn generates a history which induces all other patient depositors to wait, while all impatient ones withdraw. No bank run is the unique PBE outcome. However, as in the example above, there are several PBE strategy profiles 
and belief systems which all are identical on the equilibrium path, though they differ on off-equilibrium paths.

Analogously to the example, given any other strategy profile, there is a type vector for which some patient depositor has a profitable deviation and by leading the game down an off-equilibrium path, all patient depositors are better off to wait. By doing this, each of them receives a higher payoff.

\subsection{Only withdrawals are observed}

In this case, the reasoning of the no bank run equilibrium is identical as before. Essentially, the game's nature is that of a simultaneous move game for the patient depositors who wait. They would start withdrawing after observing more withdrawals than there are impatient depositors, but they all stick to their strategy and are rewarded with a higher consumption at $t=2$, and thus, with a larger payoff.

However, there is another equilibrium in this case that consists of all depositors withdrawing. In this case, it is not possible for the patient depositors to coordinate on waiting. In any type vector in which a patient depositor is first in the queue, by waiting the game reaches an off equilibrium path, though the other patient depositors do not observe this, and thus, are better off to withdraw. For them it is observationally equivalent to the equilibrium path in which all depositors withdraw, and thus, they cannot be all induced to wait.

Hence, there is a marked difference between the cases when only withdrawals are observed and when depositors are able to signal at a cost to subsequent depositors that they chose not to withdraw. Therefore, theoretically the asymmetry in the observability of depositors' decision (withdrawals being more visible) affect the emergence of bank runs. In the next section, we test if our theoretical finding can be verified in the laboratory. 


\section{Experimental design and results}

\subsection{Procedure}

We recruited a total of 66 subjects (31 men and 35 women) with no previous experience in coordination problems or experiments on financial decisions. We ran 2 sessions (both with 33 participants) at the Laboratory for Research in Experimental Economics (LINEEX) of Universidad de Valencia in October 2015. The participants in the experiment were students from different programs (???) at the university. The experiment was programmed using the z-Tree software (Fischbacher, 2007). Instructions were read aloud at the beginning of the experiment and questions were answered privately. The experiment began once all participants answered correctly three questions regarding the experiment.

Four depositors formed a bank, each depositor endowed with 80 ECUs. Three of the depositors were participants in the lab (patient depositors), while the last one was simulated by the computer (impatient depositor). We explained that the depositor simulated by the computer always withdrew and that payoffs depended on the participant's and her co-players' decisions. We had two treatments. In the baseline treatment, we allowed participants to observe only withdrawals, while in the other treatment (signaling treatment) they had the opportunity to reveal at a cost to subsequent depositors that they decided to keep their money deposited in the bank.

Important for our research question, in the baseline treatment we pointed out that position in the line is not known, but participants can observe if somebody (who had already decided) withdrew her funds from the bank. We made clear that observations are compatible with several decisions, e.g. not observing anything may mean that the participant is the first to decide, but also that she is the second (or third) and one (or two) other participant(s) decided to keep the money in the bank. In the signaling treatment, we allowed participants to reveal at a cost of 10 ECUs to subsequent depositors that they 
keep their funds in the bank. We used examples to explain in this case also what information the observed decisions reveal. For instance, observing that a depositor has withdrawn followed by a depositor who signaled to keep her funds reveals that the participant is either in position 3 or 4 .

In both treatments we used the same payoffs, the only difference being that if somebody signaled in the signaling treatment, then 10 ECUs were deducted from her payoffs. The payoffs were the following. If a participant is the first, second or third to withdraw, then her payoff is 100 . If she is the fourth to withdraw, then her payoff is 60 ECUs. If a participant holds and in total three / two / one depositors do so, then her payoff is 125 / 70 / 70 ECUs. Note that these payoffs allow for the coordination problem that lies at the heart of the paper and was outlined in the theory section.

To maximize the data that we collect we asked the participants in all possible information setups. ${ }^{14}$ Therefore, in the baseline treatment we asked if they wanted to withdraw or to hold after observing zero, one, two or three withdrawals. In the signaling treatment, we asked if they wanted to withdraw, to hold or to hold and make it observable after observing nothing; one / two / three withdrawal(s); one / two signal(s) that a depositor has decided to hold; and the feasible combinations of these decisions. We explained that at the end of the experiment we form banks of four (composed by three participants and the computer) randomly, then we determine randomly the sequence of decisions (including the computer that withdraws) and take into account the decision that they had given for the relevant scenario.

At the end of the experiment, the subjects filled out a questionnaire that was used to collect additional information about demographic and socioeconomic variables (sex, age, field of study, family income, belief in different

\footnotetext{
${ }^{14}$ The procedure that we used is the strategy method. Alternatively, we could have used the direct response method by grouping subjects into banks and then making them decide sequentially. However, we did not find a reliable way to devise such an experiment as it seemed impossible to eliminate that subjects hypothesize on their position in the line by considering when it was their turn to decide.
} 
institutions), risk attitudes (using the Holt-Laury test, see Holt and Laury, 2002) cognitive skills (using a new set of the cognitive reflection test, see Frederick (2005) and Toplak et al. (2014)) and overconfidence by asking the subjects how many of the cognitive reflection test questions they thought to have answered correctly. When asking about their confidence in different institution we were especially interested in their attitude towards banks so that we can control for it in our analysis. Possibly, some participants distrust banks and that may make them more prone to withdraw and hence this negative attitude may distort the analysis if we do not take it into account. There was a 0-10 scale for family income and each point represented a range of possible income. Confidence in the different institutions was expressed on a $0-10$ scale as well.

Table 1 represents the averages and standard deviations of these variables in each treatment. We see that the averages are close to each other in almost all dimensions. In fact, statistical tests reveal that we cannot reject the hypotheses that the variables are equal in both treatments. ${ }^{15}$ This suggests that subjects were appropriately randomized across treatments. When studying pairwise correlations between these variables, we find at the $5 \%$ significance level that males achieve higher Cognitive Reflection Test (CRT) scores and are also significantly less overconfident than females. Older subjects (the youngest / oldest participant was 18 /47 years old) tend to have less confidence in banks, whereas Economics and Business students trust more banks than the rest of the participants. Higher CRT scores correlate significantly with lower overconfidence. Even though we focus on the confidence in banks, we note for the sake of completeness that all the measures of confidence in the institutions except political parties were pairwise positively and significantly correlated. Unfortunately, most of the participants filled in the Holt and Laury test in strange ways, that is swithching more than once or switch-

\footnotetext{
${ }^{15}$ For each variable we carried out a t-test. Additionally, for male and studies Econ\&Bus we performed a test of proportions, while for the rest of variables a Wilcoxon ranksum test. In no case did we find any significant difference at the conventional significance levels.
} 
ing from the more risky lottery to the safer one. Seemingly, many subjects (those who switched once, but started choosing the more risky option) mixed up their choices. We have only 5 / 11 observations in the treatment without / with signaling that start choosing the less riky option and switch once to the more risky one as its expected value increases sufficiently. These observations suggest that there are no differences between the participants in the different treatments. Since the number of observations is low we omit risk aversion from the following analysis. ${ }^{16}$

\begin{tabular}{|c|c|c|}
\hline & Treatment without signaling & Treatment with signaling \\
\hline Male & $45 \%(0.51)$ & $48 \%(0.51)$ \\
\hline Age & $23.4(7.2)$ & $22.1(3.3)$ \\
\hline Risk aversion & $3.4(0.89)$ & $3.5(1.29)$ \\
\hline Studies Econ\&Business & $30 \%(0.46)$ & $18 \%(0.39)$ \\
\hline Family income & $4.3(1.92)$ & $4.8(1.57)$ \\
\hline Confidence in banks & $3.06(2.26)$ & $3.36(2.56)$ \\
\hline CRT score & $1.33(1.27)$ & $1.51(1.18)$ \\
\hline Overconfidence & $1.57(1.39)$ & $1.42(1.15)$ \\
\hline
\end{tabular}

Standard deviations are in parentheses. For all variables in each treatment we have 33 observations, except risk aversion for which we have only 5 observations in the treatment without signaling and 11 in the other one.

Table 1: Descriptive statistics of individual characteristics

Each session lasted approximately one hour, and the subjects received on average 10.64 / 11.8 Euros in the session without / with signaling, including the show-up fee of 1 euro. For the payment, ECUs were transformed into Euros using the exchange rate 10 ECUs $=1$ Euro.

\footnotetext{
${ }^{16}$ Kiss et al. (2014) find that risk aversion does not help to predict depositor decisions in a similar experiment.
} 


\subsection{Conjectures}

Having in mind that the purpose of the paper is to see if the asymmetry in the observability of previous decisions affects the emergence of bank runs, the main question is if we see a treatment effect. That is, do we observe less

withdrawals and as a consequence less bank runs in the signaling treatment? There are other conjectures based on the theoretical predictions. Namely, in the signaling treatment we do not expect any withdrawals and therefore no bank runs. Note that this prediction relies on the standard rationality assumptions that each depositor is fully rational and believes that the others are similar. Deviations from full rationality may lead to withdrawals, that is why we collected data on cognitive skills. Since we used the strategy method, we could not ask in a credible way about the beliefs that the participants had about the choices of their co-players. Withdrawals may be due to the belief that the other subjects do not understand the game and withdraw, and then withdrawing early is a best response. That is why we are interested in understanding the determinants of withdrawal in both treatments, but especially in the signaling treatment. Another sharp theoretical prediction is that participants in the signaling treatment should not use signaling, the mere existence of this possibility should suffice to wipe out bank runs.

In what follows we will investigate both individual decisions and aggregate behavior. For the latter, we define bank run in the most stringent way. There is a bank run if there is at least one patient depositor who withdraws.

\subsection{Results}

We start with some descriptive statistics about individual decisions depicted in Table 2. There are four information sets (observing nothing, 1, 2 or 3 withdrawals) that coincide in both treatments and allow direct comparison. The corresponding decisions are represented in the first four lines of Table 2. Note that given the payoffs, for the last two information sets patient depos- 
itors have a dominant strategy. Concretely, after observing two withdrawals the dominant strategy is to withdraw (and earn 100, instead of 70). In a similar vein, given the payoffs and after observing 3 withdrawals it is dominant strategy to wait (and earn 70 instead of 60). Hence, we are interested in what happens in the information sets when nothing or when a withdrawal is observed. These are key information sets to understand why bank runs arise.

\begin{tabular}{|c|c|c|c|c|c|}
\cline { 2 - 6 } & \multicolumn{2}{|c|}{ Treatment without signaling } & \multicolumn{3}{c|}{ Treatment with signaling } \\
\hline Observed decisions & $\begin{array}{c}\text { Frequency of } \\
\text { withdrawals }\end{array}$ & $\begin{array}{c}\text { Frequency of } \\
\text { waitings }\end{array}$ & $\begin{array}{c}\text { Frequency of } \\
\text { withdrawals }\end{array}$ & $\begin{array}{c}\text { Frequency of } \\
\text { waitings }\end{array}$ & $\begin{array}{c}\text { Frequency } \\
\text { of signaling }\end{array}$ \\
\hline \hline Nothing & $39.4 \%$ & $60.6 \%$ & $27.3 \%$ & $42.4 \%$ & $30.3 \%$ \\
\hline 1 withdrawal & $60.6 \%$ & $39.4 \%$ & $39.4 \%$ & $45.5 \%$ & $15.2 \%$ \\
\hline 2 withdrawals & $63.6 \%$ & $36.4 \%$ & $66.7 \%$ & $33.3 \%$ & $0.0 \%$ \\
\hline 3 withdrawals & $24.2 \%$ & $75.8 \%$ & $24.2 \%$ & $72.7 \%$ & $3.0 \%$ \\
\hline 1 withdrawal, 1 signal & - & - & $33.3 \%$ & $57.6 \%$ & $9.1 \%$ \\
\hline 1 withdrawal, 2 signals & - & - & $9.1 \%$ & $72.7 \%$ & $18.2 \%$ \\
\hline 2 withdrawals, 1 signal & - & - & $66.7 \%$ & $27.3 \%$ & $6.1 \%$ \\
\hline 1 signal & - & - & $15.2 \%$ & $45.5 \%$ & $39.4 \%$ \\
\hline 2 signals & - & - & $15.2 \%$ & $66.7 \%$ & $18.2 \%$ \\
\hline
\end{tabular}

Table 2: Individual decisions in each possible information set in both treatments

In Table 2 we see that in both cases withdrawal rates are larger in the treatment without signaling, suggesting that the asymmetry of observability really affects depositor decisions and the emergence of bank runs. If we test the null hypothesis separately for the four shared information sets that withdrawal rates are equal having as alternative hypothesis that withdrawal rates in the treatment without signaling are higher, then the test of proportions rejects this null hypothesis for the information set "observing a withdrawal" $(\mathrm{p}$-value $=0.0424)$, but fails to reject the null hypothesis in the other cases. The data suggests that as informed by the previous arguments about dominant strategies, there is no difference in the withdrawal rates when 2 or 3 withdrawals are observed and in the information set "observing nothing" we fail to reject the null hypothesis in spite of a seemingly large difference pos- 
sibly due to the low number of observations (33 in each treatment). Note that dominant strategies imply that when 2 or 3 withdrawals are observed, we should observe withdrawal rates of $100 \%$ and $0 .{ }^{17}$ The fact that we do not see these numbers suggests that participants were not fully rational.

To calculate the likelihood of bank runs, we considered in both treatments for all possible type vectors the probabilities that no patient depositor withdraws and the complementary probability represents the frequency of bank runs. For instance, examine the case when the first depositor to decide is impatient, followed by three patient depositors. When signaling is not available, then the only way to avoid bank runs is when all of the patient depositors wait. That is, the first patient depositor (who in this type vector is the second to decide, but does not know exactly her position) observes a withdrawal and decides to wait (probability 39.4\%). The next patient depositor (and also the last depositor) is also in the same situation, so she observes a withdrawal and does not know her exact position. All of them waiting when observing a withdrawal has probability $39.4 \%{ }^{\wedge} 3=6.11 \%$, so the probability of bank run is $93.89 \%$. In the signaling case for the same type vector we have to consider more cases as both waiting and signaling are non-withdrawals. Thus, all three patient depositors waiting represents a case without bank run, but also one / two / three of them signaling and the rest waiting is also a case of no bank run. However, in these cases the information sets of subsequent depositors changes. Note that considering all possible type vectors is important as our theory is silent on who goes first to the bank. ${ }^{18}$ It is relevant to see how the probability of bank run changes depending on the type vector as it may inform policy-making in the following sense. If any of the type vectors (or sequences of decision) are more prone to lead to bank runs, then decision-makers should strive to implement measures

\footnotetext{
${ }^{17}$ We can reject using t-test that the corresponding percentages are equal to 1 and 0 , respectively ( $\mathrm{p}$-values $<0.004$ in each case).

${ }^{18}$ There is no study in the bank run literature that investigates the issue of how the sequence of decision is formed.
} 
that reduce the occurence of that type vector.

Table 3 represents the probabilities of bank run in both treatments for all possible type vectors. In our case the type vector is determined by the position of the impatient depositor. In the last two columns we report the absolute and the relative decrease in the probability of bank runs.

\begin{tabular}{|c|c|c|c|c|}
\hline & \multicolumn{2}{|c|}{ Probability of bank run } & \multirow[b]{2}{*}{$\begin{array}{c}\text { Absolute } \\
\text { difference }\end{array}$} & \multirow[b]{2}{*}{$\begin{array}{c}\text { Relative } \\
\text { difference }\end{array}$} \\
\hline $\begin{array}{c}\text { Position of the } \\
\text { impatient depositor }\end{array}$ & $\begin{array}{c}\text { Treatment } \\
\text { without signaling } \\
\end{array}$ & $\begin{array}{c}\text { Treatment with } \\
\text { signaling }\end{array}$ & & \\
\hline 1 & $93.9 \%$ & $70.7 \%$ & $-23.2 \%$ & $-24.7 \%$ \\
\hline 2 & $90.6 \%$ & $69.9 \%$ & $-20.7 \%$ & $-22.9 \%$ \\
\hline 3 & $85.5 \%$ & $60.5 \%$ & $-25.0 \%$ & $-29.3 \%$ \\
\hline 4 & $92.0 \%$ & $54.2 \%$ & $-37.8 \%$ & $-41.1 \%$ \\
\hline
\end{tabular}

Table 3: The probability of bank run

Note that in each case the probability of bank runs is at least $20 \%$ smaller in the treatment with signaling, the relative differences being even larger (as the occurence of bank runs is less than $100 \%$ in the treatment without signaling). These sizable differences also indicate that there is a treatment effect and bank runs are less likely to arise when signaling is available. In the treatment with signaling the probability of bank run decreases with the position of the impatient depositor. This is in line with results in Kiss et al. (2014) who find that observing withdrawals due to the impatient depositor at the beginning of the sequence of decisions provokes more bank runs than when the impatient depositor decides in latter positions. Overall, individual decisions and aggregate behavior also suggest that there is a treatment effect and the incidence of withdrawals and bank runs is considerably lower in the treatment with signaling.

Individual behavior in the shared information sets and the prevalence of bank runs given the potential type vectors provide suggestive evidence that the possibility of signaling reduces considerably the withdrawal rate and consequently the emergence of bank runs. To understand better the determinants of withdrawal we run probit and linear probability models both 
with and without individual characteristics gleaned from the questionnaire. In all specifications standard erros are clustered on the individual level.

\begin{tabular}{|c|c|c|c|c|}
\hline & Probit & Probit & Linear probability & Linear probability \\
\hline VARIABLES & $\begin{array}{l}\text { Marginal effects } \\
\text { reported }\end{array}$ & $\begin{array}{l}\text { Marginal effects } \\
\text { reported }\end{array}$ & $\begin{array}{l}\text { Marginal effects } \\
\text { reported }\end{array}$ & $\begin{array}{c}\text { Marginal effects } \\
\text { reported }\end{array}$ \\
\hline \multirow[t]{2}{*}{ Obs. Nothing } & $-0.205^{* *}$ & $-0.204^{* *}$ & $-0.242^{*}$ & $-0.242^{*}$ \\
\hline & (0.0978) & $(0.0972)$ & $(0.132)$ & $(0.133)$ \\
\hline \multirow[t]{2}{*}{ Obs. 1 withdrawal } & -0.0293 & -0.0283 & -0.0303 & -0.0303 \\
\hline & $(0.105)$ & $(0.107)$ & $(0.112)$ & (0.112) \\
\hline \multirow[t]{2}{*}{ Obs. 3 withdrawals } & $-0.312^{* * *}$ & $-0.311^{* * *}$ & $-0.394^{* * *}$ & $-0.394^{* * *}$ \\
\hline & $(0.0662)$ & $(0.0651)$ & $(0.107)$ & $(0.108)$ \\
\hline \multirow[t]{2}{*}{ Treatment } & $-0.600^{* * *}$ & $-0.628^{* * * *}$ & 0.0303 & 0.0263 \\
\hline & $(0.108)$ & $(0.100)$ & $(0.120)$ & $(0.122)$ \\
\hline \multirow[t]{2}{*}{ Obs. Nothing $x$ Treatment } & $0.492^{* * *}$ & $0.518^{* * *}$ & -0.152 & -0.152 \\
\hline & $(0.153)$ & $(0.145)$ & $(0.186)$ & $(0.187)$ \\
\hline \multirow[t]{2}{*}{ Obs. 1 withdrawal $x$ Treatment } & $0.431^{* * *}$ & $0.455^{* * *}$ & -0.242 & -0.242 \\
\hline & $(0.134)$ & $(0.132)$ & $(0.162)$ & (0.164) \\
\hline \multirow[t]{2}{*}{ Obs. 2 withdrawals $x$ Treatment } & $0.591^{* * *}$ & $0.612^{* * *}$ & (omitted) & (omitted) \\
\hline & $(0.0781)$ & $(0.0717)$ & & \\
\hline \multirow[t]{2}{*}{ Obs. 3 withdrawals $x$ Treatment } & $0.574^{* * *}$ & $0.591^{* * *}$ & -0.0303 & -0.0303 \\
\hline & $(0.0969)$ & $(0.0927)$ & $(0.152)$ & $(0.153)$ \\
\hline \multirow[t]{2}{*}{ Obs. 1 signal } & 0.118 & 0.146 & $-0.515 * * *$ & $-0.515^{* * *}$ \\
\hline & $(0.171)$ & $(0.173)$ & $(0.108)$ & $(0.109)$ \\
\hline \multirow{2}{*}{ Obs. 2 signals } & 0.118 & 0.139 & $-0.515^{* * *}$ & $-0.515^{* * *}$ \\
\hline & $(0.148)$ & $(0.154)$ & $(0.108)$ & $(0.109)$ \\
\hline \multirow[t]{2}{*}{ Obs. 1 signal, 1 withdrawal } & $0.349^{* *}$ & $0.379^{* * *}$ & $-0.333^{* * *}$ & $-0.333^{* * *}$ \\
\hline & $(0.138)$ & $(0.135)$ & $(0.104)$ & $(0.105)$ \\
\hline \multirow[t]{2}{*}{ Obs. 1 signal, 2 withdrawals } & $0.591^{* * *}$ & $0.613^{* * *}$ & -0 & -0 \\
\hline & $(0.0767)$ & $(0.0696)$ & $(0.107)$ & (0.108) \\
\hline \multirow[t]{2}{*}{ Obs. 2 signals, 1 withdrawal } & (omitted) & (omitted) & $-0.576 * * *$ & $-0.576 * * *$ \\
\hline & & & $(0.0982)$ & (0.0991) \\
\hline \multirow[t]{2}{*}{ Male } & & 0.102 & & 0.0892 \\
\hline & & $(0.0665)$ & & $(0.0595)$ \\
\hline \multirow[t]{2}{*}{ Age } & & $8.78 \mathrm{e}-05$ & & -0.000185 \\
\hline & & $(0.00613)$ & & $(0.00571)$ \\
\hline \multirow[t]{2}{*}{ Stud. Econ\&Bus } & & -0.0543 & & -0.0456 \\
\hline & & $(0.0738)$ & & $(0.0711)$ \\
\hline \multirow[t]{2}{*}{ Family income } & & -0.0245 & & -0.0206 \\
\hline & & $(0.0152)$ & & $(0.0135)$ \\
\hline \multirow[t]{2}{*}{ Confidence in banks } & & $0.0262^{* *}$ & & $0.0217^{* *}$ \\
\hline & & $(0.0112)$ & & $(0.0102)$ \\
\hline \multirow[t]{2}{*}{ Cognitive Reflection Test } & & -0.00801 & & -0.00597 \\
\hline & & $(0.0380)$ & & $(0.0344)$ \\
\hline \multirow[t]{2}{*}{ Overconfidence } & & -0.00624 & & -0.00420 \\
\hline & & $(0.0277)$ & & $(0.0252)$ \\
\hline \multirow[t]{2}{*}{ Constant } & & & $0.636^{* * *}$ & $0.651^{* * *}$ \\
\hline & & & $(0.0856)$ & $(0.178)$ \\
\hline Observations & 429 & 429 & 429 & 429 \\
\hline R-squared & & & 0.171 & 0.193 \\
\hline Pseudo R-squared & 0.135 & 0.156 & & \\
\hline Prob $>$ chi 2 & 0 & $5.23 \mathrm{e}-11$ & & \\
\hline Prob $>F$ & & & $2.05 e-09$ & $7.93 \mathrm{e}-10$ \\
\hline Robust standard errors in parenth & & & & \\
\hline${ }^{* * *} p<0.01,{ }^{* *} p<0.05,{ }^{*} p<0.1$ & & & & \\
\hline
\end{tabular}

Table 4: The determinants of withdrawal - Probit and linear probability models

We choose as baseline the information set when two withdrawals are ob- 
served as for that case the withdrawal rates across treatments are almost equal and there is no statistically significant difference between them. In Table 4 we pool observations from both treatments and show regressions in which the dependent variable is 1 if the subject decided to withdraw and is zero otherwise. We use a treatment dummy (1 for the treatment with signaling and 0 otherwise) and interaction terms to see if there is any treatment effect. Table 4 contains the marginal effects of the variables. ${ }^{19}$

Both the probit and the linear probability model tell the same story. Compared to the withdrawal rate when two withdrawals are observed, there are significantly less withdrawals when nothing / three withdrawals are observed. Overall, we do not see a clear treatment effect when considering the information sets that coincide in both treatments. In the probit specifications, if we test if the coefficient of the treatment dummy plus the coefficient of the interaction terms (e.g. $-0.6+0.492$ in the first column for the case when nothing is observed) is equal to zero, then we fail to reject these null hypotheses at the $5 \%$ significance level. If the $10 \%$ significance level is considered, then when a withdrawal is observed, the withdrawal rate in the treatment with signaling is significantly lower (p-values are 0.0876 / 0.0701 when individual characteristics are not / are taken into account) than in the treatment without signaling. This is in line with the results of the previous statistical tests that also show significant difference at this information set. The same tests fail to show any treatment effect in the linear probability model. Significant differences arise when we turn to the information sets that only can occur in the treatment with signaling. For any information sets with at least a signal and less than two withdrawals, the rate of withdrawal in the treatment with signaling is significantly different from the overall rate in the treatment without signaling ( $\mathrm{p}$-value $<0.015$ in all cases in both probit and linear probability models). ${ }^{20}$ Depending on the exact information

\footnotetext{
${ }^{19}$ We did the same exercise using a logit model instead of the probit. The results are almost identical.

${ }^{20}$ Note that when twi withdrawals and a signal are observed, then similarly to the case
} 
set, observing signal(s) decreases the probability of withdrawal by $33-58 \%$, ceteris paribus. All this suggests that the possibility of signaling had only a moderate effect through changing behavior in the coincident information sets. Signaling helps more through creating information sets that contain at least a visible signal. Adding individual characteristics does not change coefficients markedly in no case so they seem to have only a minor role in understanding withdrawal decisions. Hence, age, gender, studying Economics or Business, family income, cognitive skills and overconfidence do not appear to be important. The only variable that affects decisions is the confidence in the banks in an unexpected way. The higher the confidence, the more likely are subjects to withdraw.

If we consider the same regressions separately for the treatments (see Table in Appendix A), the previous findings are confirmed. Compared to the baseline when two withdrawals are observed, in the treatment without signaling in no specification do we see that the withdrawal rate is lower when one withdrawal is observed, while in the treatment with signaling there is a significant difference in all specifications. Similarly to the previous results, in the treatment with signaling for any information sets with at least a signal and less than two withdrawals, the rate of withdrawal is significantly lower than in the baseline informaton set. Again, individual characteristics are not significant, except the confidence in banks that increases the probability of withdrawal.

We turn now to signaling. Remember that theory predicts that in the signaling treatment patient depositors do not withdraw and nobody signals. If we consider the confidence intervals of signaling probabilities for the different information sets, then we see that at the $95 \%$ the interval contains zero if two withdrawals / three withdrawals / a signal and a withdrawal / a signal and two withdrawals are observed. Hence, in these cases we cannot reject when only two withdrawals are observed, the dominant strategy is to withdraw given the payoffs. 
the null hypothesis that the probability of signaling is zero. This result is not surprising because when two withdrawals / three withdrawals / a signal and two withdrawals are observed, then there is a dominant strategy. In the other cases (that is if nothing / a withdrawal / a signal / two signals / two signals and a withdrawal are observed), the probability of signaling is positive. $^{21}$ This clearly suggests that participants used signaling actively at the beginning of the sequence of decision to "convince" subsequent patient depositors not to withdraw. Using signals can be seen as an attempt to reduce strategic uncertainty (that is, uncertainty about the choice of the other patient depositors, in our case, due to unobservability). Clearly, participants used signaling too much, because when already two signals are observed, it is unnecessary to signal. If we consider only the two participants that scored the maximum four points in the cognitive reflection test, then we observe that they do not signal in any information set when it does not make sense. This also hints at that many participants did not act as fully rational agents in the experiment.

The rate of signaling is always less than the rate of waiting and the difference is significant in all cases according to the test of proportions, except when nothing / a signal is observed ( $\mathrm{p}$-values $>0.3$ in both cases). This finding indicates that despite the extensive use of signaling it is still less frequently chosen than waiting. In Appendix B we report the results of a multinomial logit model in which the base category is waiting. That model only spots a significant difference between waiting and signaling (the second being lower) when two withdrawals are observed. The specifications that include individual characteristics reveal that those who are older / have more confidence in banks, are less likely to signal than to wait, ceteris paribus. In sum, individual decisions and bank run probabilities indicate that withdrawal is considerably less frequent overall in the treatment with signaling. However,

\footnotetext{
${ }^{21}$ If we restrict our attention to the $99 \%$ confidence intervals, then signaling remains significantly positive only when nothing / a signal is observed.
} 
contrary to the theoretical prediction we observe a high rate of signaling in several information sets.

\section{Conclusion}

We claim that there is an asymmetry regarding what depositor decisions can be observed: withdrawals can be more easily observed than decisions to keep the money deposited in the bank. Previous theoretical results indicate that if all previous decisions can be observed, then no bank run should happen in equilibrium. Hence, we ask what occurs if give depositors the opportunity to decrease the asymmetry present in observability. More concretely, we set up a model in which withdawals are always observed, but depositors who keep their funds deposited may make this decision visible (that is, signal), at a cost. Theoretically, depositors without urgent liquidity needs should not withdraw in this case, so bank run is eliminated as an equilibrium outcome. Moreover, no signals should be observed, as the mere existence of the possibility of signaling suffices to wipe out bank runs.

We test these predictions in the lab. We find suggestive evidence that there is a treatment effect. The probability of bank runs is markedly lower when participants are able to signal their decisions to keep their money deposited. The difference mainly does not come from the information sets that

are common in the two treatments, but it is due to the widespread use of signaling. Signaling is effective as once a signal is observed withdrawal rates become low (except when two withdrawals are also observed apart from the signal).

Based on the theoretical results and experimental findings we may answer the question posed in the title. Theoretically depositors would like to have the opportunity to show others that they do not withdraw, but they would never used the possibility. The experiment shows that depositors would not only like to have the opportunity, but they would use it also extensively. We 
believe that these findings indicate to banks and policy-makers that it would be beneficial to have ways that depositors could use as a signaling device, similarly to our model. Potentially, it could decrease the incidence of bank runs when there is no problem with the fundamentals.

\section{References}

Andolfatto, D., Nosal, E., Sultanum, B., 2014. Preventing bank runs. Working Paper 2014-021A Federal Reserve Bank of St. Louis

Andolfatto, D., Nosal, E., Wallace, N., 2007. The Role of Independence in the Green-Lin Diamond-Dybvig Model. Journal of Economic Theory 137 (1), 709-715.

Baba, N., McCauley, R., Ramaswamy, S., 2009. US dollar money market funds and non-US banks. BIS Quarterly Review, March.

Bruner, R. F., \& Carr, S. D. (2008). The Panic of 1907: Lessons learned from the market's perfect storm. John Wiley \& Sons.

Brunnermeier, M., 2001. Asset Pricing under Asymmetric InformationBubbles, Crashes, Technical Analysis, and Herding. Oxford University Press.

Calomiris, C. W., Mason, J. R., 2003. Fundamentals, panics, and bank distress during the depression. American Economic Review 93 (5), 16151647.

Cavalcanti, R. de O., Monteiro, P. K., 2015. Enriching information to prevent bank runs. Economic Theory, forthcoming

Chari, V. V., Jagannathan, R., 1988. Banking panics, information, and rational expectations equilibrium. The Journal of Finance 43 (3), 749-761. 
De Graeve, F., Karas, A., 2014. Evaluating Theories of Bank Runs with Heterogeneity Restrictions. Journal of the European Economic Association $12(4), 969-996 .$.

Diamond, D.W., Dybvig, P.H., 1983. Bank Runs, Deposit Insurance and Liquidity. Journal of Political Economy 91 (3), 401-419.

Ennis, H., 2003. Economic fundamentals and bank runs. Economic Quarterly-Federal Reserve Bank of Richmond 89 (2), 55-71.

Ennis, H., Keister, T., 2009a. Bank Runs and Institutions: The Perils of Interventions. American Economic Review 99 (4), 1588-1607.

Ennis, H., Keister, T., 2009b. Run equilibria in the Green-Lin model of financial intermediation. Journal of Economic Theory 144 (5), 1996-2020.

Ennis, H., Keister, T., 2010a. On the Fundamental Reasons for Bank Fragility. Federal Reserve Bank of Richmond Economic Quarterly 96 (1), 33-58.

Ennis, H., Keister, T., 2010b. Banking panics and policy responses. Journal of Monetary Economics 57 (4), 404-419.

Ennis, H., Keister, T., 2015. Optimal Banking Contracts and Financial Fragility. Economic Theory, forthcoming

Frederick, S. (2005). Cognitive reflection and decision making. Journal of Economic Perspectives, 25-42.

Fudenberg, D., Tirole, J., 1991. Game Theory. MIT Press.

Garratt, R.J., Keister, T., 2009. Bank Runs as Coordination Failures: An Experimental Study. Journal of Economic Behavior \& Organization 71 (2), 300-317. 
Gorton, G., 1988. Banking panics and business cycles. Oxford Economic Papers 40 (4), 751-781.

Gorton, G., Metrick, A., 2012. Securitized banking and the run on repo. Journal of Financial Economics 104 (3), 425-451.

Green, E.J., Lin, P., 2003. Implementing Efficient Allocations in a Model of Financial Intermediation. Journal of Economic Theory 109 (1), 1-23.

Gu, C., 2011. Herding and bank runs. Journal of Economic Theory 146 (1), 163-188.

Holt, C. A., \& Laury, S. K. (2002). Risk aversion and incentive effects. American Economic Review, 92(5), 1644-1655.

Ivashina, V., Scharfstein, D., 2010. Bank lending during the financial crisis of 2008. Journal of Financial Economics 97 (3), 319-338.

Iyer, R., Puri, M., 2012. Understanding Bank Runs: The Importance of Depositor-Bank Relationships and Networks. American Economic Review 102 (4), 1414-1445.

Kelly, M., O Grada, C., 2000. Market Contagion: Evidence from the Panics of 1854 and 1857. American Economic Review 90 (5), 1110-1124.

Kiss, H.J., Rodriguez-Lara, I., Rosa-García, A., 2012. On the Effects of Deposit Insurance and Observability on Bank Runs: An Experimental Study. Journal of Money, Credit and Banking 44 (8), 1651-1665.

Kiss, H.J., Rodriguez-Lara, I., Rosa-García, A., 2014. Do social networks prevent or promote bank runs? Journal of Economic Behavior and Organization 101, 87-99. 
Kiss, H.J., Rodriguez-Lara, I., Rosa-García, A., 2014. Do women panic more than men? An experimental study of financial decisions. Journal of Behavioral and Experimental Economics 52, 40-51.

Myerson, R.B., 1997. Game Theory. Harvard University Press.

Niinimäki, J. P. (2002). Do time deposits prevent bank runs?. Journal of International Financial Markets, Institutions and Money, 12(1), 19-31.

Schotter, A., Yorulmazer, T., 2009. On the dynamics and severity of bank runs: An experimental study. Journal of Financial Intermediation 18 (2), 217-241.

Starr, M.A., Yilmaz, R., 2007. Bank Runs in Emerging-Market Economies: Evidence from Turkey's Special Finance Houses. Southern Economic Journal 73 (4), 1112-1132.

Toplak, M. E., West, R. F., \& Stanovich, K. E. (2014). Assessing miserly information processing: An expansion of the Cognitive Reflection Test. Thinking \& Reasoning, 20(2), 147-168.

Wallace, N., 1988. Another attempt to explain an illiquid banking system: The Diamond and Dybvig model with sequential service taken seriously. Federal Reserve Bank of Minneapolis Quarterly Review, 12 (4), 3-16.

\section{Appendix A}

In this appendix we show probit and linear probability models similar to those in Table 4, but here we show them separately for the teratments. 


\begin{tabular}{|c|c|c|c|c|c|c|c|c|}
\hline & (1) & (2) & (3) & (4) & (5) & (6) & (7) & (8) \\
\hline & $\begin{array}{c}\text { Treatment } \\
\text { without signaling }\end{array}$ & $\begin{array}{c}\text { Treatment } \\
\text { without signaling }\end{array}$ & $\begin{array}{c}\text { Treatment } \\
\text { without signaling }\end{array}$ & $\begin{array}{l}\text { Treatment without } \\
\text { signaling }\end{array}$ & $\begin{array}{l}\text { Treatment with } \\
\text { signaling }\end{array}$ & $\begin{array}{l}\text { Treatment with } \\
\text { signaling }\end{array}$ & $\begin{array}{l}\text { Treatment with } \\
\text { signaling }\end{array}$ & $\begin{array}{l}\text { Treatment with } \\
\text { signaling }\end{array}$ \\
\hline & Probit & Probit & Linear probability & Linear probability & Probit & Probit & Linear probability & Linear probability \\
\hline VARIABLES & $\begin{array}{c}\text { Marginal effects } \\
\text { reported }\end{array}$ & $\begin{array}{c}\text { Marginal effects } \\
\text { reported }\end{array}$ & $\begin{array}{c}\text { Marginal effects } \\
\text { reported }\end{array}$ & $\begin{array}{l}\text { Marginal effects } \\
\text { reported }\end{array}$ & $\begin{array}{c}\text { Marginal effects } \\
\text { reported }\end{array}$ & $\begin{array}{c}\text { Marginal effects } \\
\text { reported }\end{array}$ & $\begin{array}{l}\text { Marginal effects } \\
\text { reported }\end{array}$ & $\begin{array}{c}\text { Marginal effects } \\
\text { reported }\end{array}$ \\
\hline \multirow[t]{2}{*}{ Obs. Nothing } & $-0.236^{*}$ & $-0.239^{*}$ & $-0.242^{*}$ & $-0.242^{*}$ & $-0.271^{* * *}$ & $-0.269 * * *$ & $-0.394^{* * *}$ & $-0.394^{* * *}$ \\
\hline & $(0.123)$ & $(0.124)$ & $(0.132)$ & $(0.136)$ & $(0.0732)$ & $(0.0655)$ & $(0.132)$ & $(0.134)$ \\
\hline \multirow[t]{2}{*}{ Obs. 1 withdrawal } & -0.0316 & -0.0304 & -0.0303 & -0.0303 & $-0.205 * * *$ & $-0.209 * * *$ & $-0.273^{* *}$ & $-0.273^{* *}$ \\
\hline & $(0.115)$ & $(0.118)$ & $(0.112)$ & $(0.115)$ & $(0.0739)$ & $(0.0720)$ & $(0.119)$ & $(0.120)$ \\
\hline \multirow[t]{2}{*}{ Obs. 3 withdrawals } & $-0.378^{* * *}$ & $-0.383^{* * *}$ & $-0.394 * * *$ & $-0.394 * * *$ & $-0.287^{* * *}$ & $-0.288^{* * *}$ & $-0.424 * * *$ & $-0.424^{* * *}$ \\
\hline & $(0.0932)$ & $(0.0936)$ & $(0.107)$ & $(0.110)$ & (0.0555) & $(0.0504)$ & $(0.108)$ & $(0.110)$ \\
\hline \multirow[t]{2}{*}{ Obs. 1 signal } & & & & & $-0.331^{* * *}$ & $-0.329 * * *$ & $-0.515 * * *$ & $-0.515^{* * *}$ \\
\hline & & & & & $(0.0474)$ & $(0.0412)$ & $(0.109)$ & $(0.111)$ \\
\hline \multirow{2}{*}{ Obs. 2 signals } & & & & & $-0.331^{* * *}$ & $-0.330^{* * *}$ & $-0.515 * * *$ & $-0.515^{* * *}$ \\
\hline & & & & & $(0.0436)$ & $(0.0390)$ & $(0.109)$ & $(0.111)$ \\
\hline \multirow{2}{*}{ Obs. 1 signal, 1 withdr } & & & & & $-0.239 * * *$ & $-0.240^{* * *}$ & $-0.333 * * *$ & $-0.333 * * *$ \\
\hline & & & & & $(0.0643)$ & $(0.0579)$ & $(0.105)$ & $(0.106)$ \\
\hline \multirow{2}{*}{ Obs. 1 signal, 2 withdr } & & & & & 0 & 0.00260 & -0 & -0 \\
\hline & & & & & $(0.103)$ & $(0.107)$ & $(0.108)$ & $(0.109)$ \\
\hline \multirow[t]{2}{*}{ Obs. 2 signals, 1 withc } & & & & & $-0.360^{* * *}$ & $-0.362 * * *$ & $-0.576 * * *$ & $-0.576 * * *$ \\
\hline & & & & & $(0.0401)$ & $(0.0390)$ & $(0.0990)$ & $(0.100)$ \\
\hline \multirow[t]{2}{*}{ Male } & & -0.0147 & & -0.0136 & & 0.120 & & 0.108 \\
\hline & & $(0.105)$ & & $(0.101)$ & & $(0.0762)$ & & $(0.0698)$ \\
\hline \multirow[t]{2}{*}{ Age } & & -0.000143 & & $1.16 \mathrm{e}-05$ & & 0.00261 & & 0.00183 \\
\hline & & $(0.00921)$ & & $(0.00859)$ & & $(0.00849)$ & & $(0.00738)$ \\
\hline \multirow[t]{2}{*}{ Stud. Econ\&Bus } & & 0.0597 & & 0.0501 & & -0.103 & & -0.0847 \\
\hline & & (0.119) & & (0.115) & & $(0.0797)$ & & $(0.0840)$ \\
\hline \multirow[t]{2}{*}{ Family income } & & -0.0130 & & -0.0112 & & -0.0196 & & -0.0174 \\
\hline & & $(0.0290)$ & & $(0.0276)$ & & $(0.0226)$ & & $(0.0193)$ \\
\hline \multirow[t]{2}{*}{ Confidence in banks } & & 0.0221 & & 0.0196 & & $0.0287^{* * *}$ & & $0.0237^{* *}$ \\
\hline & & $(0.0292)$ & & $(0.0275)$ & & $(0.0107)$ & & (0.00998) \\
\hline \multirow[t]{2}{*}{ Cognitive Reflection 1} & & 0.0129 & & 0.0142 & & -0.0159 & & -0.0140 \\
\hline & & $(0.0545)$ & & $(0.0513)$ & & $(0.0420)$ & & $(0.0375)$ \\
\hline \multirow{2}{*}{ Overconfidence } & & 0.0327 & & 0.0315 & & -0.0310 & & -0.0262 \\
\hline & & $(0.0421)$ & & $(0.0392)$ & & $(0.0359)$ & & $(0.0316)$ \\
\hline \multirow[t]{2}{*}{ Constant } & & & $0.636 * * *$ & $0.547^{* *}$ & & & $0.667^{* * *}$ & $0.652^{* *}$ \\
\hline & & & $(0.0860)$ & $(0.245)$ & & & $(0.0845)$ & $(0.272)$ \\
\hline Observations & 132 & 132 & 132 & 132 & 297 & 297 & 297 & 297 \\
\hline R-squared & & & 0.104 & 0.121 & & & 0.182 & 0.217 \\
\hline Pseudo R-squared & 0.0777 & 0.0914 & & & 0.146 & 0.180 & & \\
\hline Prob $>$ chi2 & 0.00434 & 0.0456 & & & $8.50 \mathrm{e}-09$ & 0 & & \\
\hline & entheses & & & & & & & \\
\hline
\end{tabular}

Table Appendix A: The determinants of withdrawal - Probit and linear probability models for the

\section{Appendix B}

In this appendix we show a multinomial logit model for the treatment with signaling. We use the multinomial logit model as all the regressors are case- 
specific.

\begin{tabular}{|c|c|c|c|c|c|c|c|c|c|c|c|c|}
\hline & (1) & (2) & (3) & (4) & (5) & (6) & (7) & (8) & (9) & (10) & (11) & (12) \\
\hline & \multicolumn{3}{|c|}{ Multinomial logit } & \multicolumn{3}{|c|}{ Relative Risk Ratio } & \multicolumn{3}{|c|}{ Multinomial logit } & \multicolumn{3}{|c|}{ Relative Risk Ratio } \\
\hline VARIABLES & Withdrawal & $\begin{array}{l}\text { Waiting - } \\
\text { benchmark }\end{array}$ & Signaling & Withdrawal & $\begin{array}{c}\text { Waiting - } \\
\text { benchmark }\end{array}$ & Signaling & Withdrawal & $\begin{array}{l}\text { Waiting - } \\
\text { benchma }\end{array}$ & Signaling & Withdrawal & $\begin{array}{l}\text { Waiting - } \\
\text { benchmark }\end{array}$ & Signaling \\
\hline \multirow[t]{2}{*}{ Obs. Nothing } & $-1.336 * *$ & & 1.168 & $0.263^{* *}$ & & 3.214 & $-1.427^{* * *}$ & & 1.307 & $0.240^{* * *}$ & & 3.695 \\
\hline & $(0.536)$ & & $(0.897)$ & (0.141) & & $(2.885)$ & $(0.552)$ & & $(0.954)$ & $(0.133)$ & & (3.526) \\
\hline \multirow[t]{2}{*}{ Obs. 1 withdrawal } & $-1.037^{*}$ & & 0.406 & $0.355^{*}$ & & 1.500 & $-1.095^{* *}$ & & 0.466 & $0.334^{* *}$ & & 1.593 \\
\hline & $(0.540)$ & & (0.893) & (0.191) & & (1.340) & $(0.551)$ & & (0.925) & $(0.184)$ & & (1.474) \\
\hline \multirow[t]{2}{*}{ Obs. 2 withdrawal } & -0.201 & & $-13.97^{* * *}$ & 0.818 & & $8.55 \mathrm{e}-07^{* * *}$ & -0.196 & & $-14.59 * * *$ & 0.822 & & $4.59 \mathrm{e}-07^{* * *}$ \\
\hline & $(0.504)$ & & $(0.857)$ & $(0.412)$ & & $(7.33 e-07)$ & $(0.524)$ & & $(0.867)$ & $(0.431)$ & & $(3.98 \mathrm{e}-07)$ \\
\hline \multirow[t]{2}{*}{ Obs. 3 withdrawal } & $-1.992^{* * *}$ & & -1.674 & $0.136 * * *$ & & 0.188 & $-2.076^{* * *}$ & & -1.658 & $0.125^{* * *}$ & & 0.190 \\
\hline & $(0.605)$ & & (1.316) & $(0.0825)$ & & $(0.247)$ & $(0.615)$ & & $(1.347)$ & $(0.0771)$ & & $(0.257)$ \\
\hline \multirow[t]{2}{*}{ Obs. 1 signal } & $-1.993^{* * *}$ & & 1.361 & $0.136^{* * *}$ & & 3.900 & $-2.114^{* * *}$ & & 1.551 & $0.121^{* * *}$ & & 4.718 \\
\hline & $(0.617)$ & & $(0.945)$ & $(0.0842)$ & & (3.684) & $(0.651)$ & & (1.031) & $(0.0786)$ & & (4.864) \\
\hline \multirow[t]{2}{*}{ Obs. 2 signals } & $-2.375^{* * *}$ & & 0.205 & $0.0930^{* * *}$ & & 1.227 & $-2.489^{* * *}$ & & 0.291 & $0.0830^{* * *}$ & & 1.338 \\
\hline & $(0.619)$ & & (0.978) & $(0.0575)$ & & $(1.200)$ & $(0.632)$ & & (1.034) & $(0.0525)$ & & (1.384) \\
\hline \multirow[t]{2}{*}{ Obs. 1 signal, 1 wi } & $-1.440 * * *$ & & -0.342 & $0.237 * * *$ & & 0.711 & $-1.508^{* * *}$ & & -0.306 & $0.221^{* * *}$ & & 0.737 \\
\hline & $(0.464)$ & & $(0.855)$ & $(0.110)$ & & $(0.607)$ & $(0.486)$ & & $(0.883)$ & $(0.108)$ & & (0.651) \\
\hline \multirow[t]{2}{*}{ Obs. 2 signals, $1 \mathrm{w}$} & $-2.973^{* * *}$ & & 0.118 & $0.0511^{* * *}$ & & 1.125 & $-3.102^{* * *}$ & & 0.207 & $0.0449^{* * *}$ & & 1.231 \\
\hline & $(0.747)$ & & (0.829) & $(0.0382)$ & & $(0.933)$ & $(0.744)$ & & $(0.878)$ & $(0.0334)$ & & (1.081) \\
\hline \multirow[t]{2}{*}{ Male } & & & & & & & 0.590 & & -0.139 & 1.804 & & 0.871 \\
\hline & & & & & & & $(0.427)$ & & $(0.506)$ & $(0.771)$ & & (0.441) \\
\hline \multirow[t]{2}{*}{ Age } & & & & & & & -0.00864 & & $-0.179 * *$ & 0.991 & & $0.836^{* *}$ \\
\hline & & & & & & & $(0.0397)$ & & $(0.0886)$ & $(0.0393)$ & & $(0.0741)$ \\
\hline \multirow[t]{2}{*}{ Stud. Econ\&Bus } & & & & & & & -0.377 & & 0.712 & 0.686 & & 2.038 \\
\hline & & & & & & & (0.553) & & $(0.645)$ & $(0.380)$ & & (1.313) \\
\hline \multirow[t]{2}{*}{ Family income } & & & & & & & -0.101 & & -0.0822 & 0.904 & & 0.921 \\
\hline & & & & & & & $(0.103)$ & & $(0.120)$ & (0.0932) & & $(0.110)$ \\
\hline \multirow[t]{2}{*}{ Confidence in bar } & & & & & & & $0.103^{*}$ & & $-0.191^{* *}$ & $1.109^{*}$ & & $0.826^{* *}$ \\
\hline & & & & & & & $(0.0587)$ & & $(0.0895)$ & $(0.0650)$ & & $(0.0739)$ \\
\hline \multirow[t]{2}{*}{ Cognitive Reflecti } & & & & & & & -0.0252 & & 0.323 & 0.975 & & 1.381 \\
\hline & & & & & & & $(0.235)$ & & $(0.279)$ & $(0.229)$ & & $(0.385)$ \\
\hline \multirow[t]{2}{*}{ Overconfidence } & & & & & & & -0.104 & & 0.306 & 0.901 & & 1.358 \\
\hline & & & & & & & $(0.209)$ & & $(0.234)$ & $(0.188)$ & & $(0.318)$ \\
\hline \multirow[t]{2}{*}{ Constant } & $0.894^{* *}$ & & $-1.504^{*}$ & $2.444^{* *}$ & & $0.222^{*}$ & 1.225 & & 2.209 & 3.405 & & 9.111 \\
\hline & $(0.402)$ & & $(0.794)$ & $(0.982)$ & & $(0.176)$ & (1.233) & & $(2.286)$ & (4.198) & & (20.83) \\
\hline Observations & 297 & 297 & 297 & 297 & 297 & 297 & 297 & 297 & 297 & 297 & 297 & 297 \\
\hline Pseudo R-squarec & 0.137 & 0.137 & 0.137 & 0.137 & 0.137 & 0.137 & 0.183 & 0.183 & 0.183 & 0.183 & 0.183 & 0.183 \\
\hline Prob > chi 2 & 0 & 0 & 0 & 0 & 0 & 0 & 0 & 0 & 0 & 0 & 0 & 0 \\
\hline \multicolumn{13}{|c|}{ Robust standard errors in parentheses } \\
\hline$* * * p<0.01, * * p<0$ & $.05, * p<0.1$ & & & & & & & & & & & \\
\hline
\end{tabular}

